\title{
STUDI PENCAMPURAN LABU KUNING (Cucurbita Moschata) DENGAN TEPUNG BERAS TERHADAP KARAKTERISTIK BISKUIT YANG DIHASILKAN
}

\author{
Eko Priyono $^{(1)}$, Retti Ninsix ${ }^{(2)}$, Mulono Apriyanto ${ }^{(3)}$ \\ (1) Alumni Teknologi Pangan Faperta UNISI \\ ${ }^{(2)(3)}$ Dosen Teknologi Pangan Faperta UNISI
}

mulonoapriyanto71@gmail.com

\begin{abstract}
Abstrak
Tujuan dari penelitian ini adalah bertujuan untuk mengetahui penambahan labu kuning tingkat pencampuran dan penambahan labu kuning terhadap perubahan komposisi kimia (kadar air, kadar abu , dan kadar protein) dan profil sensori yang dihasikan (ketampakan, bau dan rasa, sifat tekstural) biskuit labu kuning yang dihasilkan serta menentukan penambahan labu kuning yang tepat dalam pembuatan biskuit dengan penambahan labu kuning. Rancangan yang digunakan dalam penelitian ini adalah Rancangan Acak Lengkap (RAL) yang terdiri dari 4 perlakuan yaitu, $\mathrm{A}=$ (Labu kuning $30 \%+$ Tepung beras $70 \%), \mathrm{B}=(\mathrm{Labu}$ kuning $40 \%+$ Tepung beras $60 \%), \mathrm{C}=($ Labu kuning $50 \%+$ Tepung beras $50 \%)$, dan $\mathrm{D}=(\mathrm{Labu}$ kuning $60 \%$ + Tepung beras $40 \%$ ). Didalam pelaksanaan penelitian ini tiga tahap yang dilakukan yaitu analiasa biskuit labu kuning kadar air, kadar abu, dan kadar protein. Sehingga mendapatkan biskuit yang diinginkan. Analisa ini dilakukan untuk menentukan dan mengetahui kadar air, kadar abu, kadar protein dan organoleptik (Warna, tekstur, rasa dan aroma). Hasil terbaik biskuit yaitu perlakuan B 40\% Labu kuning $+60 \%$ Tepung beras. Dengan hasil kadar air 4,80\%, kadar abu 0,93\% kadar protein $7,00 \%$, nilai warna $3,6 \%$, tekstur $3,7 \%$, rasa $3,95 \%$, dan aroma $3,8 \%$.
\end{abstract}

Kata Kunci : Biskuit, Labu Kuning, Karakteristik

\section{PENDAHULUAN}

Salah satu bentuk produk pangan yang banyak diminati anak-anak hingga orang dewasa, mulai dari masyarakat ekonomi bawah sampai atas adalah biskuit. Kecenderungan ini berhubung dengan gaya hidup dan pola makan masyarakat yang serba berubah sebagai bentuk modernitas kehidupan, sehingga menghendaki berbagai inovasi dan kemudahan dalam memperoleh makanan. Selain makanan pokok dan sampai saat ini terigu masih merupakan bahan utama didalam pembuatan biskuit. Indonesia bukan Negara penghasil gandum, untuk mengurangi impor tepung terigu perlu dicari bahan yang dapat digunakan untuk pengganti terigu.

Biskuit adalah produk makanan kering yang dibuat dengan memanggang adonan yang mengandung bahan dasar terigu, lemak dan tanpa penambahan bahan makanan lain yang diizinkan. Umumnya bahan baku biskuit adalah terigu, namun dengan berkembangnya penelitian-penelitian mengenai pemanfaatan tepung selain terigu, maka dimungkinkan untuk mengkombinasikan 
terigu dengan tepung lain sebagai bahan baku biskuit (Yuliani et al., 2017).

Yuliani et al. (2017) melakukan penelitian tentang pengaruh penambahan tepung ampas tahu terhadap biskuit yang dihasilkan. Sedangkan dalam penelitian ini, dilakukan pencampuran labu kuning dengan tepung beras untuk menghasilkan biskuit.

Pembuatan biskuit labu kuning yang melalui beberapa tahapan pengolahan seperti pengeringan dan pencampuran adonan (formulasi) akan mempengaruhi potensinya sebagai bahan pangan. Penambanhan adonan dengan menggunakan labu kuning yang terlalu sedikit dalam pembuatan biskuit tidak akan berdampak dalam peningkatan pati resisten dan kandungan beta karoten sebagai antioksidan. Sementara itu, labu kuning yang terlalu banyak akan menyebabkan tingkat kesukaan biskuit tidak disukai. Menurut Igfar (2012), formula biskuit dengan tepung labu kuning $12 \%$ dari total tepung terigu memberikan mutu organoleptik terbaik, namun mutu gizi dan fisiknya rendah. Sementara itu menurut Nurhidayati (2011) menginformasikan bahwa pembuatan biskuit dengan $20 \%$ tepung labu kuning dari total tepung terigu menghasilkan kadar beta karoten 8,904 $\mathrm{mg} / 100 \mathrm{~g}$ yang lebih tinggi dibandingkan lainnya, sedangkan kandungan pati resistennya tidak diketahui. Hal ini menunjukkan bahwa penambahan tepung labu kuning yang tepat agar dihasilkan biskuit yang berfungsi sebagai bahan pangan dan mempunyai tingkat kesukaan yang tinggi bagi masyarakat.

Berdasarkan uraian tersebut penulis telah melakukan penelitian mengenai pengaruh penambahan labu kuning terhadap mutu biskuit yang dihasilkan dengan judul Studi Pencampuran Labu Kuning (Cucurbita
Moschata) dengan Tepung Beras terhadap Karakteristik Biskuit yang Dihasilkan.

Tujuan dari penelitian ini adalah untuk mengetahui tingkat pencampuran labu kuning yang tepat, sehingga diproleh biskuit yang mempunyai sifat kimia yang baik dan dapat diterima secara organoleptik oleh konsumen.

Manfaat dari penelitian "Studi Pencampuran Labu Kuning (Cucurbita Moschata) Dengan Tepung Beras terhadap Karakteristik Biskuit yang Dihasilkan" adalah:

1. Memberikan informasi kepada masyarakat bahwa labu kuning bisa dimanfaatkan menjadi beragam olahan makanan seperti untuk pembuatan biskuit.

2. Diharapkan terciptanya mutu biskuit labu kuning yang baik untuk dikonsumsi.

\section{METODOLOGI}

\section{Bahan}

Bahan yang digunakan pada penlitian ini antara lain : labu kuning, tepung beras ross breen, telur, gula halus, dan Margarin. Tisu roll, Alumunium foil. sedangkan bahan yang di gunakan untuk analisa kimia adalah. $\mathrm{NaOH}, \mathrm{H} 2 \mathrm{SO} 4$, Larutan K2SO4 10\%, Antifom Agent, Asbes, Alcohol.

\section{Alat \\ Yang digunakan untuk penelitian ini adalah Pisau, Talam, Baskom, Ayakan 80 mesh, Wadah pengaduk, Cetakan, Sendok, Oven, Sedangkan alat analitik yaitu timbangan analitik, Penggiling, Stopwach, Cawan, Desikator, Pipet, Tabung reaksi dll.}

\section{Metode Penelitian}

Penelitian ini dilakukan dengan menggunakan Rancangan Acak Lengkap 
(RAL) dengan 4 perlakuan 3 kali ulangan. Adapun metode pengaruh penambahan labu kuning pada tepung beras terhadap karktristik biskuit yang dihasilkan sebagai berikut :

$$
\begin{aligned}
\mathrm{A}= & 30 \% \text { Labu kuning }+ \\
& 70 \% \text { Tepung beras } \\
\mathrm{B}= & 40 \% \text { Labu kuning }+ \\
& 60 \% \text { Tepung beras } \\
\mathrm{C}= & 50 \% \text { Labu kuning }+ \\
& 50 \% \text { Tepung beras } \\
\mathrm{D}= & 60 \% \text { Labu kuning }+ \\
& 40 \% \text { Tepung beras }
\end{aligned}
$$

Masing masing perlakuan ditambahkan labu kuning dengan model rancangan yang digunakan dalam penelitian ini adalah :

$$
Y_{i j}=\mu+P_{i}+E_{i j}
$$

Keterangan :

$\mathrm{Y}_{\mathrm{ij}}=$ hasil pengamatan dari biskuit labu kuning parut yang dibuat dengan konsentrasi ke ${ }_{\mathrm{i}}$ dan ulangan $\mathrm{ke}_{\mathrm{j}}$

$\mu=$ nilai rata-rata populasi atau nilai tenggah umum

$\mathrm{P}_{\mathrm{i}}=$ Pengaruh Perlakuan $\mathrm{Ke}_{\mathrm{i}}$

$E_{i j}=$ Pengaruh Sisa Perlakuan $\mathrm{Ke}_{\mathrm{i}}$ dan Ulangan $\mathrm{Ke}_{\mathrm{j}}$

Dari hasil analisis data dilakukan dengan analisis statistik apabila $\mathrm{F}$ hitung $>\mathrm{F}$ tabel (benda nyata) maka dilanjutkan dengan uji BNT (benda nyata terkecil) pada taraf nyata $5 \%$.

\section{Pelaksanaan Penelitian}

Pelaksanaan penelitian ini terdiri dari tiga tahap yaitu : Pemilihan bahan baku, pembuatan dan proses pemanggangan.

\section{Pemarutan Daging Labu Kuning}

Proses pemarutan labu kuning dapat dilakukan dengan menggunakan parutan mesin. $5 \mathrm{~kg}$ labu kuning segar dicuci hingga bersih, kemudian dikupas kulitnya dan diiris dengan ketebalan 3-4 $\mathrm{cm}$. Irisan daging labu kuning selanjutnya diparut dengan mengunakan parutan mesin. Kemudian labu kuning diperas dengan menggunakan kain bertujuan untuk mengeluarkan air pada labu kuning. labu kuning parut setelah diperas airnya kemudian diolah menjadi biskuit.

Langkah-langkah pemarutan daging labu kuning adalah sebagai berikut.

\section{Sortasi}

Sortasi (pemilihan) dilakukan untuk memilih labu kuning, yaitu dengan tingkat yang tua dengan ciri-ciri fisik kulitnya berwarna kecoklatan, dan keras hidari buah cacat yaitu kulitnya tidak bercak-bercak hitam dan memar.

2. Pembelahan

Bertujuan untuk memudahkan dalam proses pengupasan pada kulit labu kuning

3. Pengupasan

Pengupasan dilakukan bertujuan untuk memisahkan kulit labu kuning dengan daging labu kuning sehingga memudahkan proses pemarutan.

4. Pembuangan Biji

bertujuan untuk memisahkan antara daging labu kuning yang dibutuhkan.

5. Pencucian

Labu kuning setelah dipotong dan dikupas dicuci dengan air yang bersih, untuk menghilangkan getah dan kotoran yang masih menempel.

6. Pengirisan

Pengirisan dengan ketebalan ukuran 3-4 $\mathrm{cm}$ bertujuan agar mudah dalam proses pemarutan. (Novrina Rasinta Ranonto. Dkk, 2015).

7. Pemarutan

Proses pemarutan dapat dilakukan dengan dua cara yaitu dengan menggunakan mesin pemarut kelapa dan juga bisa menggunakan parutan manual. proses pemarutan bertujuan untuk mempermudah menghilangkan 
air yang terdapat dalam labu kuning. Proses pemarutan mengggunakan pemarut mesin karena cepat dan mudah.

8. Pemerasan

Pemerasan dengan menggunakan kain bertujuan untuk memisahkan air dan ampas dari labu kuning. Hal ini bertujuan untuk mendapatkan ampas labu kuning yang diinginkan.

2. Pembuatan Biskuit Labu Kuning. (Wiwit Murdianto. 2014) yang Telah Dimodifikasi Penulis.

\section{Persiapan Bahan}

Bahan yang akan diolah dipersiapkan terlebih dahulu sesuai dengan perlakuan yang telah ditentukan, yaitu labu kuning parut yang sudah dibuang airnya, tepung beras, telur, gula halus, dan margarin.

2. Pencampuran

Parutan labu kuning dengan tepung beras dicampurkan sesuai dengan perlakuan.

3. Pengadukan

Dipersiapkan terlebih dahulu labu kuning dan tepung beras (dengan takaran sesuai perlakuan), $80 \mathrm{~g}$ margarin, 1 butir telur, $60 \mathrm{~g}$ gula halus. Margarin, telur, gula halus dan labu kuning dicampur lalu diaduk hingga rata selama 10 menit. Selanjutnya tepung beras dimasukkan dalam campuran tersebut kemudian diaduk hingga rata selama 10 menit. Setelah itu, adonan dicetak dengan ukuran persegi empat berdiameter $4 \times 2 \mathrm{~cm}$ dengan ketebalan setengah $\mathrm{cm}$ di atas loyang, kemudian dipanggang dalam oven pada suhu $140^{\circ} \mathrm{C}$ selama 45-50 menit.

4. Pencetakan

Pencetakan berfungsi untuk mencetak adonan sesuai yang diinginkan, yaitu dengan bentuk persegi 4 berdiameter $4 \times 2 \mathrm{~cm}$ dengan ketebalan setengah $\mathrm{cm}$.

5. Pemanggangan

Adonan yang telah dicetak kemudian dimasak dalam oven dengan suhu $140^{\circ} \mathrm{C}$ selama $45-50$ menit.

\section{Pengamatan}

Parameter yang diamati pada penelitian ini adalah analisa kadar air, kadar abu, analisa protein, serta uji organoleptik terhadap warana, tekstur, aroma dan rasa.

\section{HASIL DAN PEMBAHASAN}

\section{Kadar Air}

Hasil sidik ragam dari perlakuan penambahan labu kuning dalam pembuatan biskuit berbeda tidak nyata, hal ini dikarenakan $\mathrm{F}$ hitung $<\mathrm{F}$ tabel, sehingga $\mathrm{H} 0$ diterima dan $\mathrm{H} 1$ ditolak. Rata-rata kadar air biskuit setelah uji lanjut disajikan pada Tabel 1 .

Tabel 1. Rata-Rata Hasil Analisa Kadar Air Biskuit dengan Penambahan Labu Kuning.

\begin{tabular}{|c|rc|}
\hline Perlakuan & \multicolumn{3}{|c|}{ Kadar Air (\%) } \\
\hline $\mathrm{D}=($ Labu kuning 60 \% + Tepung beras 40 \%) & $8,19 \quad \mathrm{a}$ \\
\hline $\mathrm{C}=($ Labu kuning 50 \% + Tepung beras 50 \%) & $5,60 \quad \mathrm{a} \quad \mathrm{b}$ \\
\hline $\mathrm{B}=($ Labu kuning 40 \% + Tepung beras 60\%) & 4,80 & $\mathrm{~b}$ \\
\hline $\mathrm{A}=($ Labu kuning 30 \% + Tepung beras 70 \%) & $4,00 \quad \mathrm{~b}$ \\
\hline
\end{tabular}

Keterangan : angka pada tiapa lajur yang diikuti oleh huruf yang sama berbeda tidak nyata pada tingkat kepercayaan 5\% menurut uji BNJ 
Hasil analisa kadar air menunjukan bahwa jumlah kadar air tertinggi terdapat pada perlakuan D (Labu kuning 60\% + Tepung beras 40\%) karena perlakuan D menggunakan labu kuning sebesar 150 gram sehingga akan menghasilkan jumlah kadar air yang sangat tinggi terhadap biskuit tersebut yaitu $8,19 \%$. dan kadar air terendah terdapat pada perlakuan A (Labu kuning 30\% + Tepung beras $70 \%$ ) rendahnya kadar air yang terdapat pada perlakuan $\mathrm{A}$ dikarenakan penambahan labu kuning sangat sedikit yaitu 75 gram sehingga menghasilkan rendah kadar air pada perlakuan A yaitu 4,00\% .

Tingginya kadar air pada perlakuan D dikarenakan pada saat penambahan labu kuning sebesar $150 \mathrm{~g}$. akan mengakibatkan peningkatan kadar air yang terdapat pada biskuit tersebut. karena air yang terkandung di dalam labu kuning sangat tinggi yaitu sebesar 9,1\% / 100 gram labu kuning.

Rendahnya kadar air pada perlakuan A dikarenakan dalam penambahan ampas labu kuning diperlakuan A semakin sedikit yaitu sebesar 75 gram. Kadar air setiap perlakuan berbeda hal ini dikarenakan keterkaitan air dalam bahan pangan juga berbeda-beda, kandungan air dalam pangan dapat dibedakana air terikat dan air bebas (Winarno dalam Yuliana et al., 2014).

Secara keseluruhan besarnya kadar air yang dikandung oleh biskuit dengan perlakuan A, dan B yaitu perlakuan penambahan labu kuning 30\% dan $40 \%$ masih memenuhi persyaratan yang ditetapkan oleh SNI yaitu maksimum 5\%. Kecuali untuk perlakuan C, dan D yaitu perlakuan penambahan labu kuning 50\% dan $60 \%$ kadar airnya melebihi SNI.

Hasil analisa statistik menunjukkan bahwa perlakuan penambahan labu kuning memberikan pengaruh yang berbeda nyata terhadap kadar air biskuit yang dihasikan.
Semakin besar penambahan labu kuning yang ditambahkan kedalam adonan biskuit maka kadar air biskuit yang dihasilkan semakin meningkat. Hal ini disebabkan karena labu kuning memiliki kadar air 91,2\% lebih tinggi (Dir. Gizi Depkes RI 1981).

\section{Kadar Abu}

Abu adalah zat anorganik sisa hasil pembakaran suatu bahan organik. Beberapa vitamin dan semua mineral bersifat larut dalam air sehingga dapat terbuang bersama cairan yang digunakan untuk memesak. Pemasakan dengan cara cepat dan menggunakan sedikit atau tanpa air merupakan pilihan tepat untuk mempertahankan vitamin dan mineral. Kandungan abu dalam bahan pangan dan komposisinya tergantung pada macam bahan dan cara pengabuanya. Menurut (Amelia 2005), bahwa kadar abu ada hubungannya dengan mineral suatu bahan. Hasil analisis sidik ragam menujukan bahwa pecampuran labu kuning memberikan pengaruh berbeda nyata dengan $\mathrm{F}$ hitung $\geq \mathrm{F}$ tabel terhadap kadar abu Biskuit yang dihasilkan menurut uji lanjut BNJ pada taraf nyata 5\%. Rata-Rata kadar abu berdasarkan perlakuan penambahan labu kuning dapat dilihat pada tabel 2 .

Hasil analisa statistik menunjukan bahwa jumlah kadar abu tertinggi terdapat pada perlakuan D (Labu kuning $60 \%$ + Tepung beras $40 \%$ ) karena perlakuan D menggunakan labu kuning sebesar $150 \mathrm{~g}$ labu kuning mengandung residu anorganik dalam jumlah besar sehingga menghasilkan abu 3,28\%. dan kadar abu terendah terdapat pada perlakuan B (Labu kuning 40\% +Tepung beras $60 \%$ ) rendahnya kadar abu pada perlakuan B dikarenakan penambahan labu kuning hanya sebesar 100 gram sehingga kadar abu pada biskuit masih memenuhi syarat yaitu $0,93 \%$. 
Tabel 2. Rata-Rata Kadar Abu Biskuit Berdasarkan Perlakuan Penambahan Labu Kuning

\begin{tabular}{|c|c|}
\hline Perlakuan & Kadar Abu (\%) \\
\hline $\mathrm{A}=($ Labu kuning 30 \% +Tepung beras 70 \%) & 0,94 \\
\hline $\mathrm{B}=($ Labu kuning $40 \%+$ Tepung beras 60 \%) & 0,93 \\
\hline $\mathrm{C}=($ Labu kuning 50 \% + Tepung beras 50 \%) & 1,05 \\
\hline $\mathrm{D}=($ Labu kuning $60 \%+$ Tepung beras $40 \%)$ & 3,28 \\
\hline
\end{tabular}

Tingginya kadar abu biskuit pada perlakuan D juga dapat disebabkan adanya penambahan labu kuning yang mengandung residu anorganik dalam jumlah besar, karena ukuran partikel labu kuning yang masih kasar sementara tepung beras yang begitu halus, kasarnya tekstur labu kuning mengakibatkan adanya serat yang berada dalam biskuit.

Selain adanya kandungan mineral pada labu kuning, kandungan protein yang teinggi menjadi faktor meningkatnya abu pada biskuit, hal ini sesuai dengan pernyatan (Amelia,2005) bahwa kandungan abu tidaklah sepenuhnya mewakili bahan anorganik pada makanan, abu dapat berasal dari bahan organik seperti sulfur dan fosfor dari protein.

Secara keseluruhan besarnya kadar abu yang dikandung oleh biskuit dengan perlakuan A, B, dan C. Yaitu perlakuan penambahan labu kuning 30\%, 40\%, dan $50 \%$ masih memenuhi persyaratan yang ditetapkan oleh SNI yaitu maksimum $1,5 \%$. Kecuali untuk perlakuan D (Labu kuning 60\% + Tepung beras 40\%) kadar abunya melebihi SNI.

Hasil analisa statistik menunjukan bahwa perlakuan penambahan labu kuning memberikan pengaruh yang berbeda nyata terhadap kadar abu biskuit yang dihasilkan. Perlakuan B (Labu kuning $40 \%+$ Tepung beras $60 \%$ ) berbeda nyata dengan perlakuan C (Labu kuning $50 \%+$ Tepung beras $50 \%$ ) dan $\mathrm{D}$ (Labu kuning 60\% + Tepung beras 40\%). Berbeda tidak nyata dengan perlakuan B (Labu kuning 40\% + Tepung beras 60\%). Sedangkan perlakuan B (Labu kuning $40 \%+$ Tepung beras $60 \%$ ) berbeda tidak nyata dengan A (Labu kuning $30 \%+$ Tepung beras $70 \%$ ). Semakin besar penambahan labu kuning yang ditambahkan kedalam biskuit maka kadar abu biskuit yang dihasilkan semakin meningkat. Hal ini disebabkan karena labu kuning menyumbang kadar abu lebih tinggi (Amelia, 2005). Sehingga jumlahnya pada produk biskuit yang semakin ditambahkan labu kuning bertambah karena dalam pelaksanaan proses pembuatan labu kuning belum menerapkan seluruh prinsip hignis sanitasi antara lain proses pengolahan (pemarutan, pemerasan) sehingga mengandung residu anorganik (abu) lebih tinggi (Marwati, 2011).

\section{Kadar Protein}

Sudarmadji (1999) menyatakan kadar protein merupakan salah satu kelompok bahan nutrisi, tidak seperti bahan makronien lainnya (karbohidrat dan lemak). Protein ini berperan lebih penting dalam pembentukan biomelekul dari pada sumber energi. Maka protein ini juga dapat dipakai sebagai sumber energi. Keistimewaan protein adalah strukturnya yang mengandung unsurunsur N, C, H dan O. yang tidak dimiliki oleh lemak atau karbohidrat (Winarno, 1997). Hasil pengamatan terhadap protein biskuit labu kuning dapat dilihat pada tabel 3 . 
Tabel 3. Rata-Rata Kadar Protein Biskuit Berdasarkan Perlakuan Penambahan Labu Kuning

\begin{tabular}{|c|c|}
\hline Perlakuan & Kadar Protein (\%) \\
\hline $\mathrm{A}=($ Labu kuning 30 \% + Tepung beras 70 \%) & 6,67 \\
\hline $\mathrm{B}=($ Labu kuning 40 \% + Tepung beras 60 \%) & 7,00 \\
\hline $\mathrm{C}=($ Labu kuning 50 \% + Tepung beras 50 \%) & 7,90 \\
\hline $\mathrm{D}=($ Labu kuning 60 \% + Tepung beras 40 \%) & 8,25 \\
\hline
\end{tabular}

Hasil analisa kadar protein menunjukan bahwa jumlah kadar protein tertinggi terdapat pada perlakuan $\mathrm{D}$ (Labu kuning $60 \%+$ Tepung beras 40 $\%)$ tingginya kadar protein pada perlakuan D dikarenakan perlakuan D menggunakan labu kuning labu kuning sebesar 150 gram sehingga kadar protein yang dihasilkan biskuit tinggi akan protein yaitu sebesar $8,25 \%$. dan kadar protein terendah terdapat pada perlakuan A (Labu kuning $30 \%+$ Tepung beras 70 $\%$ ) rendahnya kadar protein pada perlakuan A karena perlakuan A menggunakan labu kunig sebesar 75 gram lebih sedikit dari pada perlakuan D sehingga terdapat rendah kadar protein pada biskuit terersebut yaitu sebesar 6,67\%. Dari jumlah rata-rata tabel 09 . Dapat dilihat bahwa semakin besar jumlah penambahan labu kuning maka akan semakin tinggi kadar protein pada biskuit tersebut.

Tingginya kadar protein pada perlskuan D (Labu kuning $60 \%+$ Tepung beras $40 \%$ ) karena labu kuning memiliki protein $1,1 \%$ / 100 gram. Hal ini dikarenakan penambahan labu kuning dalam jumalah besar yaitu $60 \%$ akan meningkatkan jumlah protein, menurut (Syafitri, 2009) kandungan protein pada labu kuning sebesar 1,1 gram.

Rendahnya kadar protein pada perlakuan A (Labu kuning 30\% + Tepung beras 70\%) dibandingkan dengan perlakuan $\mathrm{B}, \mathrm{C}$ dan $\mathrm{D}$ dikarenakan pada perlakuan tersebut penambahan labu kuning sangat tinggi.
Perlakuan A tidak terlalu besar dalam penambahan labu kuning yaitu 75 gram. Sehingga kadar protein yang terkandung didalam biskuit labu kuning tersebut lebih kecil, dibanding dengan perlakuan yang B, C dan D.

Namun setelah menjadi produk biskuit protein menurun dikarenakan pada saat proses pengolahan dengan cara pemanggangan yang terlalu tinggi maka akan mengakibatkan menurunya kadar protein pada biskuit labu kuning tersebut. Hal ini sesuai dengan pendapat (Syafitri, 2009). bahwa cara pengovenan yang begitu tinggi mempengaruhi kehilang protein selama proses pengovenan.

Hasil penelitian menunjukan bahwa kadar protein yang dihasilkan belum sesuai dengan rekomendasi Standar Nasional Indonesia SNI bahwa kadar protein pada biskuit yaitu minimum 9\% sedangkan kadar protein yang terdapat pada biskuit kurang dari 9\%. Tetapi perlakuan D yang hampir mendekati SNI yaitu sebesar $8,25 \%$.

\section{Uji Organoleptik}

\section{Warna Biskuit}

Warna merupakan salah satu aspek penting dalam hal penerimaan konsumen terhadap suatu produk pangan. Warna dalam bahan pangan dapat menjadi ukuran terhadap mutu, warna juga dapat digunakan sebagai indikator kesegaran atau kematangan (Winarno, 1992). Ratarata warna biskuit setelah uji lanjut dapat dilihat pada tabel 4. 
Tabel 4. Rata-Rata Penilaian Organoleptik terhadap Warna Biskuit

\begin{tabular}{|c|c|}
\hline Perlakuan & Warna \\
\hline $\mathrm{A}=($ Labu kuning $30 \%$ Tepung beras 70 \%) & 3,8 \\
\hline $\mathrm{B}=($ Labu kuning $40 \%$ Tepung beras 60 \%) & 3,6 \\
\hline $\mathrm{C}=($ Labu kuning 50 \% Tepung beras 40 \%) & 3,7 \\
\hline $\mathrm{D}=($ Labu kuning 60 \% Tepung beras 30\%) & 3,3 \\
\hline
\end{tabular}

Berdasarkan hasil uji mutu hedonik untuk para meter warna pada tabel 10 menujukkan bahwa tingkat kesukaan panelis terhadap warna terhadap warna biskuit labu kuning dan tepung beras berkisar antara 3,3-3,8 \%. Warna yang paling disukai panlis terdapat pada perlakuan A (Labu kuning $30 \%+$ Tepung beras $70 \%$ ) dengan skor $3,8 \%$. Karena kandungan antosianin pada labu kuning tidak tidak begitu bereaksi dikarenakan perlakuan A penambahan labu kuning hanya sebesar 75 gram.

Warna yang kurang disukai panelis terdapat pada perlakuan D (Labu kuning $60 \%$ Tepung beras 30\%) yaitu sebesar $3,3 \%$. Dikarenakan semakin tinggi konsentrasi labu kuning yang diberikan maka warna kuning yang ada pada biskuit labu kuning semakin gelap dikarenakan kandungan antisionin pada labu kuning meningkat, Sehingga warna biskuit labu kuning pada perlakuan D tidak disukai oleh panelis.
Semakin tinggi konsentrasi labu kuning yang diberikan maka warna kuning yang ada pada biskuit labu kuning semakin gelap karena kandungan antisianinnya meningkat. Antisianin ini merupakan pigmen yang bertanggung jawab untuk warna kuning, biru, ungu, violet, dan merah pada tumbuhtumbuhan dan buah-buahan.

\section{Tekstur Biskuit}

Menurut kartika dkk (1988), tekstur merupakan sensasi tekanan yang dapat diamati dengan mulut (pada waktu digigit, dikunyah, ditelan). Pengujian tekstur bertujuan untuk mengetahui tingkat penerimaan dan kesukaan panelis terhadap tekstur biskuit labu kuning pada berbagai perlakuan. Parameter pengujian tekstur mengacu pada tingkat kesukaan panelis terhadap kerenyahan (kemudahan sampel untuk digigit) biskuit labu kuning. Hasil pengamatan terhadap tekstur biskuit labu kuning dapat dilihat pada tabel 5 .

\section{Tabel 5. Rata-Rata Penilaian Organoleptik terhadap Tekstur Biskuit}

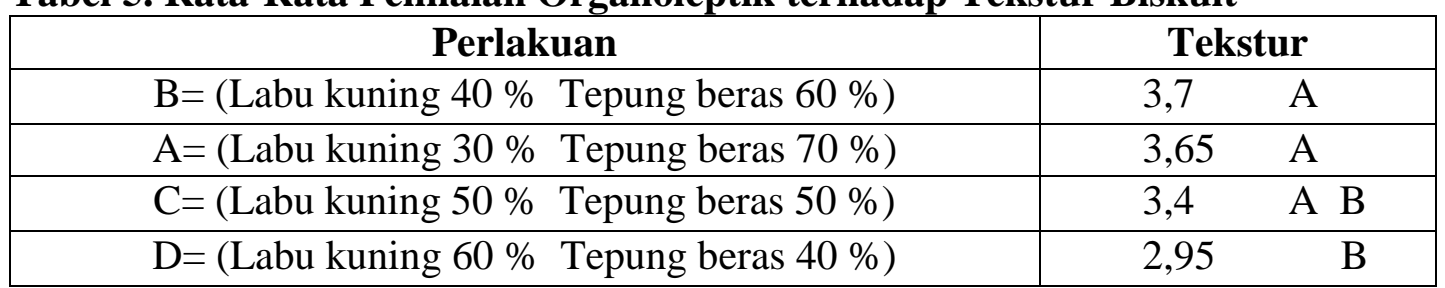

Keterangan : angka pada tiapa lajur yang diikuti oleh huruf yang sama berbeda tidak nyata pada tingkat kepercayaan 5\% menurut uji BNJ

Penelitian penulis terhadap tekstur biskuit berkisar antara 2,95 \% $3,7 \%$ nilai tertinggi terhadap tekstur biskuit yaitu pada perlakuan B (Labu kuning 40
$\%$ Tepung beras $60 \%$ ) dengan nilai 3,7 $\%$ dan nilai terendah yaitu pada perlakuan D (Labu kuning $60 \%$ Tepung beras $40 \%$ ) dengan nilai $2,95 \%$. 
Tekstur biskuit yang kasar di pengaruhi oleh serat yang ada pada labu kuning. Pada perlakuan D (Labu kuning $60 \%$ Tepung beras $40 \%$ ) permukaan biskuit lebih kasar dikarenakan proses penambahan labu kuning yang begitu besar sehingga mengakibatkan tekstur pada permukaan biskuit menjadi kasar, sehingga panelis tidak menyukai perlakuan D.

Tekstur biskuit yang paling disukai panelis terdapat pada perlakuan B (Labu kuning $40 \%$ Tepung beras $60 \%$ ) yaitu dengan nilai 3,7 \% karena perlakuan $\mathrm{B}$ menggunkan 100 gram labu kuning dan 150 gram tepung beras, sehingga tekstur yang dihasilkan biskuit labu kuning perlakuan B sangat disukai panelis, karena serat kasar pada labu kuning tidak terlihat. karena tepung beras yang digunakan lebih besar di banding dengan labu kuning. Sehingga biskuit yang dihasilkan lebih menarik dan lebih disukai panelis.

Semakin banyak labu kuning yang ditambahkan menyebabkan tekstur biskuit yang dihasilkan tingkat kesukaannya menjadi semakin menurun. Selain faktor tepung beras, pemanggangan dan pencampuran, faktor lain yang mempengaruhi tekstur biskuit, gula, margarin, dan telur. (Winarno, 1992).

\section{Rasa Biskuit}

Rasa timbul akibat adanya rangsangan kimiawi yang dapat diterima oleh indera pencicip atau lidah. Rasa adalah faktor yang mempengaruhi penerimaan produk pangan (Winarno,1997). Hasil pengamatan terhadap rasa biskuit labu kuning disajikan pada tabel 6 .

Tabel 6. Rata-Rata Penilaian Organoleptik terhadap Rasa Biskuit

\begin{tabular}{|c|c|}
\hline Perlakuan & \multicolumn{2}{|c|}{ Rasa } \\
\hline $\mathrm{B}=($ Labu kuning 40 \% Tepung beras 60\%) & $3,95 \quad \mathrm{a}$ \\
\hline $\mathrm{A}=($ Labu kuning 30 \% Tepung beras 70 \%) & 3,9 a b \\
\hline $\mathrm{C}=($ Labu kuning 50 \% Tepung beras 50 \%) & $3,8 \quad \mathrm{a} \quad \mathrm{b}$ \\
\hline $\mathrm{D}=($ Labu kuning 60 \% Tepung beras 40 \%) & $3,35 \quad \mathrm{~b}$ \\
\hline
\end{tabular}

Keterangan : angka pada tiapa lajur yang diikuti oleh huruf yang sama berbeda tidak nyata pada tingkat kepercayaan 5\% menurut uji BNJ

Uji organoleptik terhadap rasa biskuit berkisar antara 3,35\% - 3,95\%, nilai tertinggi terdapat pada perlakuan B (Labu kuning $40 \%$ Tepung beras $70 \%$ ) yaitu sebesar 3,95\%, perlakuan B dengan penambahan labu kuning dengan berat 100 gram menghasilkan biskuit yang disukai karena menghasilkan biskuit yang lebih renyah.

Rasa biskuit yang kurang disukai terdapat pada perlakuan D (Labu kuning $60 \%$ Tepung beras $40 \%$ ) yaitu dengan nilai 3,35 \% hal ini dikarenakan penambahan labu kuning yang terlalu besar akan menyebabkan tingkat kesukaan biskuit tidak disukai, dikarenakan rasa pada biskuit dipengaruhi oleh bahan dasar yang digunakan. Bahan yang digunakan dalam pembuatan biskuit ini memiliki rasa sedikit langu sehingga dengan penambahan labu kuning terlalu tinggi. Akan menghasilkan rasa yang tidak disukai oleh panelis.

Rasa merupakan faktor yang juga penting, dari suatu produk makanan. Komponen yang dapat menimbulkan rasa yang diinginkan tergantung dari senyawa penyusunannya. Umunya bahan pangan tidak hanya terdiri satu rasa saja 
akan tetapi gabungan dari berbagi macam rasa yang terpadu sehingga menimbulkan citra rasa yang utuh. Citra rasa merupakan akibat integrasi atau saling tindak isyarat yang dihasilkan oleh rangasangan bau, rasa dari makanan atau minuman. Persepsi citra rasa dimulai dengan penilayan visual untuk mengetahui dan menentuka apakah hal itu dapat dimaka atau sebaliknya (Abdullah, A, 2005).

Menurut (Soekarto, 1985). Bahwa rasa merupakan faktor yang penting dalam memutuskan bagi konsumen untuk menerima atau menolak suatu makanan. Meskipun parameter yang lain baik, jika rasa tidak enek atau tidak disukai, maka produk akan ditolak.

\section{Aroma Biskuit}

Aroma suatu produk ditentukan saat zat-zat volatile masuk kedalam saluran hidung dan ditanggapi oleh sistem penciuman (Winarno, 1992). Pembauan disebut pencicipan jarak karena manusia dapat mengenal enaknya makanan yang belum terlihat hanya dengan mencium baunya dari jarak jauh (Soekarto, 1985). Hasil pengamatan terhadap aroma biskuit ampas labu kuning setelah uji lanjut dapat dilihat pada tabel 7 .

Tabel 7. Rata-Rata Penilaian Organoleptik terhadap Aroma Biskuit

\begin{tabular}{|c|c|}
\hline Perlakuan & Aroma \\
\hline $\mathrm{C}=($ Labu kuning 50 \% Tepung beras 50\%) & $4,25 \mathrm{a}$ \\
\hline $\mathrm{B}=($ Labu kuning 40 \% Tepung beras 60\%) & $3,8 \mathrm{a} \mathrm{b}$ \\
\hline $\mathrm{D}=($ Labu kuning 60 \% Tepung beras 40\%) & $3,5 \mathrm{~b}$ \\
\hline $\mathrm{A}=($ Labu kuning 30 \% Tepung beras 70\%) & $3,4 \mathrm{~b}$ \\
\hline
\end{tabular}

Keterangan : angka pada tiapa lajur yang diikuti oleh huruf yang sama berbeda tidak nyata pada tingkat kepercayaan 5\% menurut uji BNJ

Berdasarkan hasil uji mutu hedonik untuk parameter aroma pada tabel 13 menujukan bahwa tingakat kesukaan panelis terhadap aroma biskuit labu kuning berkisar antara 4,25 - 3,4\%. Aroma yang paling disukai terdapat pada perlakuan C (Labu kuning $50 \%+$ Tepung beras $50 \%$ ) dengan skor $4,25 \%$, hal ini dikarenakan perlakuan $\mathrm{C}$ penambahan labu kuning dan tepung beras seragam yaitu 125 gram, sehingga aroma khas biskuit tersebut benar-benar terasa. Dan disukai panelis.

Aroma yang kurang disukai terdapat pada perlakuan A (Labu kuning $30 \%+$ Tepung beras $70 \%$ ) dengan skor $3,4 \%$. Hal ini disebakan karena pelakuan A dengan penambahan labu kuning yang lebih sedikit hanya sebesar 75 gram maka aroma yang dihasilkan pada biskuit pada perlakuan A kurang disukai panelis, Karena aroma khas labu kuningnya tidak begitu terasa.

Aroma makanan banyak menentukan kelezatan bahan makanan tersebut, dalam hal bau lebih banyak sangkut-pautnya dengan alat panca indera, bau-bauan baru dapat dikenali bila terbentuk uap, dan molekul-molekul komponen bau tersebut harus sempat menyentuh silia sel olfaktori (Winarno, 1992). Aroma berasal dari aroma panggang karena reaksi maillard (Mariana, 2007) antara gula dan asam amino.

\section{KESIMPULAN}

\section{Kesimpulan}

Berdasarkan hasil penelitian studi pencampuran labu kuning dengan tepung 
bersa terhadap karaktristik biskuit yang dihasilkan dapat diambil kesimpulan bahwa dari semua perlakuan bahwa hasil perlakuan yang paling baik terdapat pada perlakuan B (labu kuning 40\% + tepung beras $60 \%$ ). Dengan menghasilkan rasa biskuit yang paling disukai karena menghasilkan biskuit yang lebih renyah, sedangkan tekstur biskuit yang dihasilkan sangat baik sesuai dengan cetakan biskuit, sedangkan warna pada biskuit yang terbaik juga terdapat pada perlakuan B karena kandungan antosian pada labu kuning tidak begitu bereaksi dikarenakan ada perlakuan B penambahan labu kuning hanya sebesar 100 gram. Berdasarkan hasil uji hedonik untuk parameter aroma biskuit labu kuning aroma yang paling disukai hal ini dikarenakan perlakuan B dengan penambahan labu kuning $100 \%$ dan tepung beras $150 \%$ sehingga aroma biskuit labu kuning tidak begitu ber aroma labu kuning.

\section{Saran}

Berdasarkan hasil penelitian ini disarankan perlu penelitian lebih lanjut tentang umur simpan "biskuit" dari hasil penambahan labu kuning dengan tepung beras. Satu hal yang menarik apa bila ada yang berminat untuk melenjutkan penelitian ini dengan pengamatan secara mikrobiologis agar dalam waktu penyimpanan biskuit bisa bertahan lebih lebih lama.

\section{DAFTAR PUSTAKA}

Abdullah, A., 2005 Prinsip Penilaian Sensori, Universitas Kebangsaan Malaysia UNRI Press Pekanbaru

Amelia M. R, Nina D, Trisno A. 2005 Penetapan Kadar Abu.Fakultas Ekologi Manusia. Bogor.

Asmoro L. C, Kumalaningsih S, Mulyadi A. F. 2012. Karaktristik Organoleptik Biskuit dengan
Penambahan Tepung Ikan Teri Nasi ( Stolephorus Spp. ). Fakultas Teknologi Pertanian, Universitas Bandung

Assosistion Of Official Analytical Chemist, 2005. Official Method Of Analysis Of The Assosistion Of Official Analytical Chemist. Arlington : The Assosistion Of Official Analytical Chemist, inc.

BSN. 1992. SNI Mutu dan Cara Uji Biskuit (SNI 01-2973-1992). Badan Standarisasi Nasional. Jakarta.

Damayanthi E. Rice Bran Stabilization and $\gamma$-Oryzanol Content of Two Local Padd Varieties "IR 64" and "Cisadane Muncul". J Teknologi dan Industri Pangan. 2007; XV(1): 11-9.

Direktorat Gizi Departemen Kesehatan RI. 1981. Daftar Komposisi Bahan Makanan. Jakarta: Bhatara Aksara.

Farida, A., 2008. Patiseri jilid 1-3. Direktor jendral Manajemen Pendidikan Dasar dan Menengah Departemen Pendidikan Nasional. Jakarta

Fellows, P. J 2004. Food Processing Technology, Principle and Practice. 2nd Ed.CRC Press, England.

Ginting, L.N. 2011. Manajemen Agribisnis Labu Kuning atau Waluh. Managemen Agribisnis: 1-48.

Godber J, Xu Z, Hegsted M, Walker T: "Rice and Rice Bran Oil in Functional Foods Development". Louisiana Agriculture, 2002, 45 (4): 9-10.

Hanafi, A,. 1999. Potensi Tepung Ubi Jalar Sebagai Bahan Subsitusi Tepung Terigu Pada Proses Pembuatan Cookies yang Disuplementasi dengan Kacang Hijau. Skripsi Sarjana Jurusan Teknologi Pangan dan Gizi, 
Fakultas Teknologi Pertanian. IPB, Bogor.

Igfar, A. (2012) Pengaruh Penambahan Tepung Labu Kuning (Cucurbita Moschata) Dan Tepung Terigu Terhadap Pembuatan Biskuit. http://www .unhas.ac.id/tekpert/ seminar/index.php. (Diakses 17 Februari 2017).

IImah M. 2014 Penentuan Kadar Air Dan Kadar Abu Dalam Biskuit. Fakultas Ilmu Tabiyah Dan Keguruan. Universitas Islam Negri Syarif Hidayatul Jakarta.

Ir, Sutrisno Koswara, MSi, 2009 Teknologi Pngolahan Beras (Teori Dan Praktek)

Kartika, B., P. Hastuti dan W. Supartono, 1988. Pedoman Uji Indrawi Bahan Pangan. PAU Pangan dan Gizi UGM. Yokyakarta

Lohachoompol V, Srzednicki G, Craske $J$ (2004) The change of total anthocyanins in blueberris and their antioxi-dant effter drying and freezing. J Biomed Biotechno 5:248-252

Made Astawa, 2000. Beras dan Tepung Beras. Bahan untuk Majalah Femina Jakarta.

Manly, D. J. R 1998. Biscuits. Cookie, and Craker Manufacturing Manuals., Woodhend Publishing Ltd. England

Manly, D. J., R. 2000 Technology of Biscuit, Cracker, and Cookies Third Edition. Woodhend Publishing Limited and CRC Press LCC England.

Mariana, L., 2007. Pembuatan roti manis. Diklat Pengolahan Serealia dan Kacang-kacangan. Departemen Agroindustri Vedca.P4TK Cianjur. Jawa barat

Marwati, 2011. Pembuatan Tepung Ubi Jalar. http://epetani.deptan.go.id/.
Akses Tanggal 7 April 2017, Tembilahan

Novrina Rasinta Ranonto. Dkk, 2015. Retensi Karoten Dalam Berbagai Produk Olahan Labu Kuning (Cucurbita moschata Durech).

Nurhidayati (2011) Kontribusi Mp-Asi Biskuit Bayi Dengan Substitusi Tepung Labu Kuning (Cucurbita Moschata) dan Tepung Ikan Patin ( Pangasius Spp) terhadap Kecukupan Protein Dan Vitamin A. E-prints.undip.ac.id (Diakses 17 Februari 2017)

Oluwamukomi, M.O., Oluwalana, I.B., and Akinbowale, O.F,. 2011. Phiysicohemical and Sensory Properties of Wheat-Cassava Composite Biscuit enriched with soy Flour. African Journal of Food Science Vol 5(2) pp.50-60

Rasdiansyah, dan Z.F. Rozali. 2011. Penggunaan Pasta Labu Kuning Sebagai Bahan Biofortifikasi Vitamin A Pada Roti Tawar. Teknologi Dan Industry Pertanian Indonesia, 3(3): 7-11

Ripi, V.I. 2011. Pembuatan Dan Analisis Kandungan Gizi Tepung Labu Kuning (Cucurbita Moschata Duch.) Teknologi Industry, 1 (2): 32-41

Soekarto,E., 1985. Penilaian Organoleptik untuk Pangan dan Hasil Pertanian. Bahatara Karya Aksara, Jakarta

Sudarmadji, S. Haryono dan Suhardi. 1997 Prosedur Analisa Untuk Bahan Makanan Dan Pertanian . Liberty. Yokyakarta

Syafitri D. 2009. Pengaruh Subsitusi Tepung Ampas Tahu pada Kue Ulat Sutra terhadap Kualitas Organoleptik dan Kandungan Gizi. Fakultas Teknik Universitas Negri Semarang.

Widowati Sri. 2011. Pemanfaatan Hasil Samping Penggilingan Padi dalam 
Menunjang Sistem Agroindustri di Pedesaan. Buletin AgroBio: 4(1): 33-38

Winarno F. G. 1992. Kimia Pangan dan Gizi. Jakarta: Gramedia Pustaka Utama.

Winarno F. G. 1997. Kimia Pangan Gizi. Penerbit PT. Gramedia Utama. Jakarta.

Winata, V. Y. 2014. Kualitas Biskuit Dengan Kombinasi Tepung Kacang Mete (Annacardium Occidentale L.) Dan Tepung Kulit Singkong (Manihot Esculenta). Skripsi Fakultas Atmajaya Yokyakarta Fakultas Teknologi Program Studi Biologi, Yokyakarta.

Wiwit M. 2014. Formulasi Labu Kuning Dan Kelapa Parut Terhadap Karaktristik Kimia Dan Sensori Pada Pembuatan Cookies.
Yanuwardana, basito dan D.R.A. Muhamad. 2013. Kajian Karaktristik Fisikokimia Tepung Labu Kuning (Cucurbita Moschata) Termodifikasi dengan Variasi Lama Perendaman dan Konsentrasi Asam Laktat. Teknosains Pangan, 2(2) : 75-83

Yuliana, dan Novitasari, Rifni. 2014. Pengaruh Substitusi Tepung Terigu dengan Tepung Pisang Kepok (Musa paradisiacal formatypica) terhadap Karakteristik Mie Kering yang Dihasilkan. Jurnal Teknologi Pertanian. Universitas Islam Indragiri. Vol 3, No.1 Tahun 2014. Pp: 1-14. ejournal.unisi.ac.id.

Yuliani, Sartika dan Mardesci, Hermiza. 2017. Pengaruh Penambahan Tepung Ampas Tahu terhadap Karakteristik Biskuit yang Dihasilkan. Jurnal Teknologi Pertanian. Universitas Islam Indragiri. Vol.6, No.1 Tahun 2017. Pp: 1-11. ejournal.unisi.ac.id. 